\title{
The Political Economy of India's Post-planning Economic Reform: A Critical Review
}

\section{By Kalim Siddiqui ${ }^{1}$}

In World Review of Political Economy, 2018, Vol. 9, issue 2.

\begin{abstract}
:
A quarter of a century has passed since neo-liberal economic policies were first adopted in India in 1991 and it is timely to review their outcome. The study is important because there currently seems to be a gap in the literature, since most published research has highlighted India's overall GDP growth rates. In the post-planning reform period, India reduced the role of the state and public sector, and dismantled controls, while increasing the role of the market and private sector within the economy. As a result, foreign capital investment and foreign exchange reserves improved. The study intends to examine what happened to the industrial sector after neoliberalism was adopted. This article primarily focuses on the discourse about neoliberal economic policy and its effects on Indian economy, especially in the context of sectoral change. The article centres on a critical review of the available literature and a contribution to the substantive topics indicated in the title. The study contributes to the existing literature by focusing on the industrial and the agricultural sector, which has been neglected by the mainstream economists, who have focused largely on growth rates.
\end{abstract}

Key words: Indian economy, neoliberalism, economic structuring, growth rates and poverty.

JEL codes: F43, L60, L98

\section{Introduction}

The aim of this article is to analyse the pro-market economic reforms in India and, at the same time, to consider its performance and its limitations. It will also discuss the economic rationale for neoliberal reforms. The Indian economy has a very high average annual GDP growth of $7 \%$ per annum, and is an impressively vibrant democracy; where parliamentary elections are regularly hold. However, these appearances can be misleading.

A quarter of a century has passed since liberal policies were first adopted in India in 1991 and it is timely to review their outcome. There has been a considerable rise in the inflow of capital and in exports, but imports have also risen. Foreign investment is not taking place in Indian manufacturing, as was the case in China; instead, foreign capital has largely been invested in services, urban property and speculative activities (Siddiqui, 2017a).

Oil prices rose in response to the Iraqi invasion of Kuwait in 1990, and the Soviet Union collapsed in 1991, the same year India experienced a balance of payment crisis. This crisis led them to ask the IMF for an emergency loan in 1991, and there was a shift in Indian policy towards foreign capital (Nayyar, 2017). Economic liberalisation was launched by the Congress government following the 1991 economic crisis, although pro-market policies had already been started in the early 1980s. However, as a result of the severe economic crisis in 1991, the government opted for a quick break from dirigiste policies in favour of economic liberalisation. In May 1991, India's reserves amounted to barely three weeks' worth of imports and foreign investor confidence was also at rock bottom. Under these circumstances, the government approached the IMF, pledging its gold reserves. As part of the bailout

\footnotetext{
${ }^{1}$ The author would like to thank Barry Pavier and John Day for helpful comments and suggestions on earlier version. The author has benefitted from comments by two anonymous referees in producing the final version of this paper.

Address for correspondence: Kalim Siddiqui teaches senior lecturer in International Economics at the University of Huddersfield, Queensgate HD1 3DG, UK. e-mail: k.u.siddiqui@hud.ac.uk
} 
conditions, the IMF imposed an economic liberalisation programme (also known as Washington Consensus) ${ }^{2}$ which included the usual measures: privatisation, a greater role for market forces, relaxation of the licence-permit raj (licence-permit regime) more openness to foreign investment and financial deregulation (Joshi and Little, 1994).

Yeldan's study (2006) on Turkey's IMF-led economic reforms is very relevant to this current study on very similar IMF-led economic reforms in India. Turkey introduced a structural adjustment programme (SAP) nearly a decade earlier than India and it would be interesting to look at its experience. "[SAP] was marked by commodity trade liberalization and export promotion along with price reform aimed at reducing the state's role in economic affairs....This policy manoeuvre paved the way for injection of liquidity into the domestic economy in terms of short-term foreign capital (flow of "hot money"). Such inflows, enabled, on the one hand, financing the accelerated public sector expenditures, and provided, on the other hand, relief from the increased pressures of aggregate demand on domestic markets by way of the cheapening costs of imports...[also] gave rise to significant shifts in income distribution and to an intensification of the on-going processes of transfer of the economic surplus from the industrial/real sectors and wage labor, in particular, towards the financial sectors" (Yeldan, 2006:199). Who further notes that: "Consequently, finance was elevated over industry and the real sphere of the economy, and the financial sector drifted to the speculation of short-term capital flows in a process that has been characterised as casino capitalism” (Yeldan, 2006:201).

In 2015-16 the Indian economy grew faster at 7\% annually than it had done for the two previous years. This equals China's growth rate and is much faster than that of other BRICS countries (Brazil, Russia, India, China and South Africa). In fact, both Brazil and Russia experienced negative growth rates for the same period (Siddiqui, 2016a). By way of comparison, the GDP growth rate in developed countries was about $2 \%$ for 2015-16, while developing countries on average grew about $4.4 \%$ for the same period. This means India's growth rate was impressive. However, if we consider a longer period, then the picture is less impressive because this growth rate is not consistent and has been much slower in the past (Patnaik, 2015).

In order to understand fully the liberal reform of 1991, it is necessary to remember India's economic situation in the previous decade. During the 1980s, the government faced a mounting fiscal crisis and was also keen to increase government spending, and consequently decided to borrow from overseas. As Nayyar notes:

It [economic crisis] was triggered by an increase in world crude oil prices, following Iraq's invasion of Kuwait in August 1990. This minor oil shock was the proverbial last straw that broke the camel's back [...] The balance of payments situation became almost unmanageable. The fear of acceleration in the rate of inflation loomed large [...] Growing agitation on reservations for Other Backward Classes compounded problems. Even so, in early October 1990, [V.P.] Singh [then India's Prime Minister] authorised initiating negotiations with the IMF [...] on the realisation that India was close to defaulting on its international payments obligations and an understanding that the IMF was needed not simply as a lender of last resort but also for its imprimatur essential to restore international confidence (Nayyar, 2017:42).

\footnotetext{
${ }^{2}$ The Washington Consensus was first coined by Williamson (1990). The policy measures included trade liberalisation, deregulation, and privatization. For more thorough analysis is provided in Rodrik (2002, 2011).
} 
In July 1991 an exchange rate adjustment was made and as a result, the Indian rupee depreciated by $23.3 \%$ to the US dollar. Other measures were taken to reduce fiscal deficit sharply, which in turn led to a steep rise in fuel prices while subsidies for fertilizers and food were drastically reduced. The government proclaimed that the pro-market policies would increase economic growth, efficiency and competition. Under IMF's liberalisation programme, the government decided to substantially reduce the role of the state, placing greater reliance on market forces. This meant that the role of the public sector in production and investment was significantly reduced. In addition, the economy was open to foreign investment and trade, and technology. Thus, it seems that the focus was on the supply side only (Girdner and Siddiqui, 2008).

It was claimed that adopting these liberal policies would not only solve the balance of payments crisis, but that foreign capital would bring new technology and enhance India's international competitiveness and, consequently, would rapidly increase exports. (Joshi and Little, 1994) However, little attention was paid to the fact that imports of foreign technology could be capital-intensive and labor-displacing rather than creating jobs and would certainly not prove to be a substitute for domestic technological capabilities.

It seems that with the removal of restrictions on imports of technology, the foreign firms will find it more attractive to setup collaborative enterprises, and will boost domestic production along with foreign capital, technology and management skills. Another important factor that contributed towards increased inflows of capital was due to further capital liberalisation measures taken by the government. Such measures provided opportunities for retail lending in portfolios of Indian commercial banks. Suddenly, the influx of foreign capital provided excessive liquidity in the system, which could be lent to consumers to purchase houses, automobiles and consumer durables. These credits were also extended without any collateral and on the basis of speculative projections of borrowers' current earning profiles. Such individuals often borrowed excessive money from multiple sources without revealing that to the creditors. The availability of external funds resulted in an increase in debt-finance demand in the 1990s. As Chandrasekhar (2013:20) notes: "even the rate of overall and industrial growth during the 1990s was not very different from that in the 1980s, there was evidence of an incipient change in the regime of accumulation. There were two aspects to this change. The first was that private consumption expenditure on manufactured consumption goods and private investment in housing began to play a more important (relative to public expenditure) in driving demand and growth. Second, associated with this were signs that debt-financed private consumption expenditure was displacing debt-financed public expenditure as a leading stimulus for growth".

However, it seems that on the growth front, the turning point in India's economic growth came in the 1950s and 1980s, not in the 1990s. The liberalisation did contribute to increase in growth rates from the mid-1990s onwards and, in addition, the world economic boom helped India's economy to maintain growth rates for a longer period from 2003 to 2007. India benefited from reforms largely due to the essential foundations that had been built during the preceding decades of the pre-reform period. (Rodrik, 2011) However, in two crucial areas, India's reforms were far less satisfactory, namely, in the agricultural sector and in the manufacturing. The most important failure of the liberal reforms has been that despite high economic growth, job creation has been negligible. The open economy and liberalisation of the new technology meant importing foreign technology, which had a job-displacing effect rather than creating employment (Nagaraj, 2017). 
The other crucial failure has been the persistence of mass poverty. If we accept the official data on poverty, then rapid growth has not made much impression on the number of poor people. Official data indicates that in 2011-12 at least $25 \%$ of India's 1.2 billion inhabitants were living in absolute poverty. It should not be forgotten that in 2012, one-third of the world's poor were living in India. Finally, inequality has risen sharply during the market reform period. For example, between 1991 and 2010, the Gini coefficient of consumption inequality based on NSSO (National Sample Survey Office) data rose from 29.6 to 36.8 (Nayyar, 2017).

In the light of the recent study by Dani Rodrik (2016) there is a need to revisit the issue of industrialisation, which is still very important for creating employment, diversifying the economy and removing low productivity workforce from agriculture. However, according to this study, the increased global integration and liberalisation has led to de-industrialisation in some developing countries. It is very important for a country like India to draw some lessons from such a potentially adverse impact, which could be a huge destabilising factor. Another, important point is that the blind and open technology imports from advanced economies may be less suitable for developing economies like India as technologies currently in use in advanced economies are labour saving and capital using and hence are not meant to create employment. While on the contrary, India needs to create a large number of jobs in the industrial sector, due to persistence of high levels of unemployment and growing population (Chandrasekhar and Ghosh, 2015).

For a heavily populated country such as India, the manufacturing sector still seems to be the only path which the traditional economy can take in order to secure better living conditions for the people. Therefore, industrialisation is seen as being crucial to transforming a backward economy with low productivity (Nicholas, 2005). By this, we do not mean to suggest that the solution lies in the type of industrialisation that is likely to create environmental and ecological crisis. However, this particular discussion lies outside the scope of this study. Instead, the focus is on analysing the importance of the industrial sector in India. There seems to be a gap in the literature because most research has chosen to highlight the overall GDP growth rates of the Indian economy (Srinivasan, 1993), but little has been written about the industrial sector's importance, performance and near stagnation in overall job creation since economic reforms were launched in 1991. India's industrial sector has languished at around 16\% of GDP (which is much less than that of China or any other country at India's stage of economic development), 12\% of the total workforce and about three-quarters of the merchandise exports. Over the past six decades the manufacturing sector has grown on average over $6 \%$ per annum, representing a major breakthrough since the end of colonial rule (Bagchi, 1976).

The manufacturing share in GDP was at its peak level of $17.3 \%$ in $1979-80$, went down to an average of approximately $16 \%$ between 1995-96 and 2007-08, but thereafter declined to $12.9 \%$ in 2014. (Nayyar, 2017) India's share in value added goods and manufactured exports within the developing world has declined slowly since 1996-97; in contrast to this, China, Indonesia, Malaysia and Thailand have all seen their share of manufactured exports risen during the same period. The results from the manufacturing sector contradict the claims by mainstream economists that pro-market reforms in India would increase manufacturing output and efficiency (Routray, 2015).

Despite the liberal reforms, India was unable to catch up with other East Asian economies, especially in building a viable manufacturing sector and increasing its share in manufactured 
exports. There is no doubt that its services share has increased, but outsourcing has generated very little employment. The government is now talking about a "Made in India" campaign to raise manufacturing output so that it represents a $25 \%$ share of GDP by 2022. (Siddiqui, 2016a)

\section{Crisis and the Policy Options}

The government portrayed this change in 1991 as a watershed in Indian policy making declaring that it is was removing the interventionist policy which had been in place since independence and had included regulation of markets and foreign capital, public sector building programmes, and a priori plan as to how economic resources should be allocated. With the launching of neoliberal reforms, the role of the government was minimised: instead of being the regulator of the market economy it became the facilitator of the market mechanism (Siddiqui, 2015).

Soon after independence in 1950, the government saw maintaining some form of control on foreign capital as a prerequisite for ensuring long-term economic development and national sovereignty. India chose to pursue economic development with a highly regulated mixed economy, because it was realised that relying largely on market and private investors to allocate resources would not help what was then a backward colonial economy with very low productivity and mass poverty to achieve its aims (Patnaik, 2014). These were to diversify its economic activity, to catch up with the developed countries and also to improve living conditions for the majority of the population who were facing extreme poverty and deprivation. At that time it was considered that regulating and disciplining large landholders and industrialists would prevent them from pursuing profit to the detriment of social benefits. India's post-independence industrial policy was based on import-substitution industrialisation from1950 to1991. Putting this into a more historical perspective, in the first half of the $20^{\text {th }}$ century, prior to independence, India's GDP growth rate was very low, at less than $0.9 \%$ annually. However, after independence, its economy grew at about $4 \%$ per annum, which was much higher than in the earlier period, but still lower than other East Asian economies (Patnaik, 2013a).

Since the early 1980s, India's rich, including the urban middle classes who had been direct beneficiaries of past government intervention and the public sector, had become disillusioned with the slow growth and looked towards global capital for a solution to this impasse. Policy options such as increased borrowing from global capital markets in the 1980s and increased integration with global finance were seen as the only available options. At the same time, the credit-led boom in the advanced economies from the 1990s until 2008 meant that India benefited from a rise in export demands and foreign capital inflows, which created local asset-market bubbles (Rodrik, 2011; Stiglitz, 2010).

In the mid-1980s the government began to rely increasingly on external borrowing to cover its rising deficits. However, a major U-turn in economic policy occurred in May 1991 when India decided to approach the IMF for a bail-out and, in return, the IMF recommended the adoption of a 'structural adjustment programme' i.e. economic liberalisation. Economic liberalisation involves adopting more open trade and capital accounts policies. The economic liberalisation policy was fully supported by the mainstream economists and international financial institutions. T.N. Srinivasan, a proponent of economic liberalisation noted: 
"They [the reforms] were solidly based on an understanding of what went wrong with Indian development strategy since 1950 that delivered neither rapid growth nor appreciably greater equity". (Srinivasan, 1993: 258)

Similar views were expressed by Jagdish Bhagwati who identified the three main policy factors that stifled India's growth and efficiency as: "extensive bureaucratic controls over production, investment and trade; inward looking trade and foreign investment policies, and a substantial public sector, going well beyond the conventional confines of public utilities and infrastructure" (Bhagwati, 1993:48). Others, such as Joshi and Little argued that India's industrial policy was responsible for its persistent fiscal deficits and periodic balance of payment crises. In their opinion, "India's control system was not only micro-economically inefficient but macro-economically perverse" (Joshi and Little, 1994:3). However, those developing countries that underwent neo-liberal reforms including financial de-regulation found themselves trapped with high levels of interest rates and increased attacks of speculative hot money flows into real estate property and financial sectors, rising neverending spiral of consumers' debts, and increased dependence on imports and jobless growth (Siddiqui, 1998).

The adoption of neo-liberal policies was expected to raise levels of competition in the Indian economy and to make domestic firms more competitive with the increased presence of foreign firms and technology. It was said that market-friendly policies would facilitate an outward-oriented export-led growth trajectory. However, the fact that restructuring the capacities of domestic industries requires time was ignored as was the fact that building a reputation among customers and expanding markets takes even longer. In short, increasing exports is a complex task, while trade liberalisation immediately pushes up imports, as the elite's demand for consumer goods increases. This led to the widening of the trade and current account deficit in the balance of payments (Siddiqui, 2016b).

Economic success is measured by international institutions, such as the IMF, the World Bank and the WTO, which support neoliberal reforms and measure success in terms of the confidence that foreign investors have in the Indian economy. This is judged by the amount of foreign capital inflows, especially finance capital coming into the country (Stiglitz, 2010; Rodrik, 2002). Since the adoption of economic liberalisation, inflows of foreign capital have risen sharply. For instance, in 1991 total foreign investment was just US\$ 100 million, which rose to US\$ 3 billion in 1993-94. This was due to a sharp increase in portfolio flows into equity and debt markets in India. Foreign investment rose further to US\$ 5 billion in 1996-97 and then rapidly declined due to the East Asian financial crisis in 1997. However, foreign capital inflows soon started to rise again and reached the same levels as during the pre-1997 peak. In 2003-04 the rules were further relaxed and incentives were extended to foreign investors, with long-term tax on capital gains being abolished, which made India a virtual tax haven. Foreign investment began to increase after 2003 and India was viewed as a favoured destination by foreign investors. Capital inflows had reached US\$ 62 billion in 2007-08 at the time of global financial crisis, (Balakrishnan, 2010) and it reached to US\$ 65 billion in 2015 (Siddiqui, 2017a). Such a sharp increase would not have been possible without the relaxation in laws governing foreign capital and repatriation of profits from India. The sharp increase in non-debt inflows of foreign capital, especially in portfolio and foreign direct investment indicates a new trend. Initially, this coincided with the rise in the public expenditure in the late 1990s. But later on, government spending was not available with the adoption of fiscal conservatism (Chandrasekhar, 2013). 
Certainly, in the post-reform period, and especially since 2003, the availability of excess capital has been used to finance India's current account deficit; within foreign capital inflows, the portfolio component seems to be more volatile. This is not related to the development of the Indian economy. The increased flow of capital has produced a huge injection of liquidity into the economy, which has triggered a credit boom that has increased growth but this boom is riding on a credit bubble. For example, the ratio of bank credit to GDP in India increased from $22 \%$ to $60 \%$ between 2003 and 2015. This credit boom has diverted credit away from industries to personal loans used to obtain consumer goods and housing. This does not provide any relief to the poorer sections of society (Siddiqui, 2016a).

In contrast, China accumulated substantial amounts of foreign exchange reserves due to long periods of surpluses on its current account. In short, India has not earned its foreign reserves as happened in China; rather, foreign investors choose to keep it in return for short-term higher returns and are eligible to repatriate their capital if and when they choose to do so. This development has increased India's vulnerability and its reliance on foreign capital, especially finance capital which required the adoption of austerity policies to ensure that India remained an attractive destination for foreign capital. However, this policy measure may have a negative effect on the income of the majority of India's population (Patnaik, 2013a).

\begin{tabular}{|l|l|l|l|l|l|l|}
\hline & \multicolumn{2}{|l|}{ India } & \multicolumn{2}{l|}{ China } \\
\hline & 1990 & 2000 & 2015 & 1990 & 2000 & 2015 \\
\hline Agriculture & 29.30 & 23.00 & 13.00 & 27.10 & 13.10 & 10.10 \\
\hline Industry & 26.90 & 26.10 & 26.30 & 41.30 & 45.90 & 46.60 \\
\hline Manufacturing & 16.70 & 16.40 & 14.20 & 32.70 & 32.10 & 29.60 \\
\hline Services & 43.80 & 50.50 & 55.50 & 31.20 & 41.00 & 45.10 \\
\hline
\end{tabular}

Table 1: Structure of the Economy (\% of GDP)

Source: World Bank, 2016.

The sectoral composition of the economy has been excessively weighted in favour of services and excessively against the agricultural sector (See Table 1). India's industrial sector's percentage share to GDP slightly declined from $26.90 \%$ in 1990 to $26.30 \%$ in 2015 . In contrast to India's, China industrial share to GDP has not only been higher, but also has risen from 41.30 to 46.80 for the same period (Siddiqui, 2017b; Routray, 2015).

Recent high growth rates were due to rapid growth in the service sector, driven by a worldwide boom in the IT sector. Meanwhile, the share of agriculture in the GDP has continued to decline, from 55\% in 1950 to about $13 \%$ in 2015 (See Table 1). Moreover, the share of incomes of those working in the services rose rapidly. The near stagnation in manufacturing in India and the relatively consistent income from this sector has meant that it continues to employ the same number of workers. The situation is described by the economists as "jobless growth" (Patnaik, 2013a).

\section{Development Theories}

During the post-war period a number of discussions took place about development theory. The major contributors in the developed countries were Ragnar Nurkse, Arthur Lewis, Joan Robinson, Nicholas Kaldor, and Albert Hirschman, to cite but a few. They were concerned with the development possibilities for countries with low levels of per capita incomes and 
low productivity. Most of these countries were in Africa, Asia and Latin America and they had had a long period of colonial rule and also suffered from low investment, and widespread poverty and illiteracy. Nurkse (1953) argued that the key requirement in such underdeveloped economies would be the need for capital formation. Soon after Lewis (1954) suggested that in labor surplus economies, agricultural laborers working for subsistence wages could be transferred to manufacturing. The logic was that the labor could shift from a low productivity sector to one with greater productivity i.e. manufacturing. This would relieve the burden from agriculture and the share of industry in GDP would increase; as a consequence, the income in services would rise. Lewis (1954) focused on this transfer of labor from agriculture as a means of driving industrialisation and modernisation. For him, the agricultural sector would play a crucial role as a supplier of surplus labor to industry. It would supply inputs and raw materials to industry. Over time, the supply of agricultural surpluses would act as a driving force for industrial growth. However, Lewis appeared to be focusing only on the supply side of the problem and he did not discuss the demand side for the industrial goods.

Neo-classical economists overlooked the experience of colonisation and economic transformation of the developing countries in the $19^{\text {th }}$ century and how these economic changes continue to impact on their present-day economies. The benefits that the industrialised countries derived from their colonial markets are ignored in neo-classical arguments (Krueger, 1987). The Colonies provided markets, supplied raw materials and cheap labor. The economic policies were formulated in the Colonies to suit the metropolis. For Britain, for example, the access to colonial markets provided assured markets for their manufactured goods but at the same time British protectionism ensured that Indian manufactured goods could not be sold into British markets. The supply of cheap raw materials from India minimised inflation in Britain. Until the end of the 19th century, nearly half of British exports consisted of cotton textiles, destined chiefly for India and China, ironically at the same time that these two countries were themselves experiencing deindustrialisation, massive unemployment and poverty (Bagchi, 1976).

In Britain, the traditional industries such as handicrafts faced destruction in the 19th century due to the rapid industrial development. However, the jobs created in the modern industries were much higher than those lost in their traditional counterparts. The experience in the Colonies including India was quite different. The British government used protective measures not only during the early years of the Industrial Revolution but right the way through until the 1840s, but similar protective measures were not available for Indian industries. In India, handloom weaving and hand-spinning constituted the largest handicraft industries, employing large numbers of workers, and the loss of these jobs had a very depressive effect on the whole economy. As Bagchi (1976:154) observes: "Within India herself, when de-industrialisation drove laborers to seek their living in agriculture, they faced a highly imperfect market, the most important complementary asset, land, being already concentrated in the hands of landlords".

In the colonies, David Ricardo's 'comparative advantage' meant that they had to specialise in the production and export of raw materials. The adoption of these policies led to the perpetuation of mass poverty and famine in India for the whole of the 19th century and the first half of the 20th. India proved useful to Britain as the surplus extracted from India was used to settle its deficits with the other industrialised countries whose goods it had imported. During the period 1900-1946, India experienced near stagnation in per capita income, while GDP growth was minimal. Maddison estimated that growth in national output was only $0.9 \%$ per annum and per capita growth was dismal, being just 0.04\% per annum (Maddison, 1995). 
Neoliberals emphasise the benefits of free market, competition and efficiency and the role of individuals in determining economic outcomes. According to them, any distortions are associated with government intervention and regulation of markets and the crucial issue of aggregate employment determination. They argue that under the free market, prices of the factors of production adjust to ensure that all factors are fully employed. The economy selfadjusts to full employment in the long-run. Any distortions by the government involving the use of monetary and fiscal policy to raise employment merely generate inflation. They maintain that economic development requires rapid GDP growth, which has a "trickle-down effect", benefitting the poor. Finally, it is claimed that the higher growth rate generate large revenues for the state exchequer and thus enabling the government to invest more and create more jobs (Bhagwati, 1993).

\section{The Interlinkage between the Industrial and Agricultural Sector}

The growth of industry appears to be very important to economic growth and the well-being of the population of developing countries such as India. Nicholas Kaldor identified most critical issue is the 'Laws of Economic Development' in his book (1967) Strategic Factors in Economic Development. He views the wider impact of the manufacturing sector as follows: 1) Higher growth in the manufacturing sectors can also lead to an increase in labor productivity; 2) Productivity in the non-manufacturing sector increases as the manufacturing sector expands; 3) Manufacturing is an engine of growth, not only because of higher productivity but also because of the external economies it generates, including forward and backward linkages; 4) As the manufacturing sector expands, it provides job opportunities for the surplus labor in the agricultural sector, which ultimately reduces levels of unemployment and poverty. Kaldor (1967) emphasised that the growth of agriculture surplus is an essential condition for increasing the purchasing power necessary for sustaining industrial expansion. For him, industrial growth depends on stimulus provided by demand from agriculture sector. In order to achieve sustained industrial growth, the terms of trade between agriculture and industry should be in favour of the former as it would benefit the latter through increased purchasing power. He observed that increasing agricultural productivity through technological innovation would generate a surplus that would keep food prices low, while increasing the demand for industrial goods.

Industrialisation is important but the identity of the central actor driving the industrialisation process is equally important. Past experiences from various countries show that industrialisation is not merely an instrument of economic growth but also has an in-built mechanism for distributing the costs and benefits of growth. However, it seems that the opening up of domestic markets and free trade as strategies for industrialisation can be incompatible in the present circumstances for the late-industrialising countries. For example, South Korea is characterised by active state intervention in the economy and the accumulation process was sustained. State protection of certain strategic industries was considered necessary there in order to bring about a situation where integration with the world economy would lead to the development of industries and expansion in employment domestically (Amsden, 2003).

During the last four decades, the rapid economic transformation of the East Asian countries has become the most important development in the world economy. For instance, development initially in Japan, then South Korea and most recently in China has been the most spectacular and the most widely discussed. However, proponents of 'outward-looking' 
industrialisation policy overlook the differences among the East Asian countries that successfully followed this policy. For example, Japan and South Korea had almost no foreign direct investment capital flows, while Hong Kong, Singapore and more recently, China, have been dominated by inflows of foreign capital (Siddiqui, 2009).

In the pre-liberalisation period from 1980-81 and 1990-91, the annual industrial growth was 7.8\%. By contrast, for the initial period of liberalisation i.e. 1990-91 to 2011-12, the industrial growth rate was $6.2 \%$. This means the period of liberalisation is characterised by slower industrial growth rates than the preceding periods. Moreover, if we look at the entire pre- and post-liberalisation period industrial growth rates were slower in the latter period. For example, from 1950-51 to 1990-91 the entire period of dirigisme, industrial growth rate was on average $6.32 \%$ annually, while in the period $1990-91$ to $2011-12$ it was $6.28 \%$, and even lower if we consider the post-2012 period (see Figure 1).

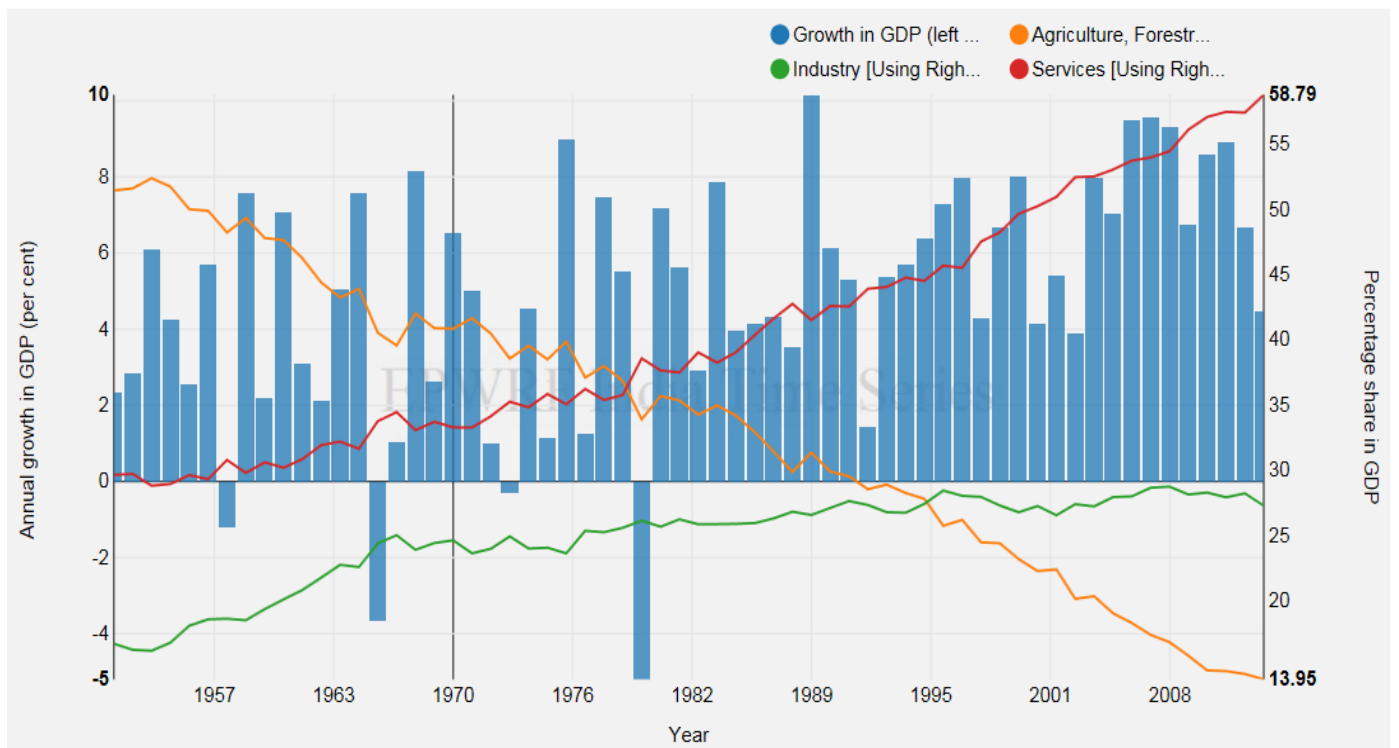

Figure 1: India's Growth and Sectoral Share in GDP (2004-05 series) at constant prices, 1950-2015.

Source: Economic and Political Weekly, EPWRF India Time Series Database, http://www.epwrfits.in/index.aspx (accessed on 10 November, 2017).

However, industrial slowdown or lower growth rates is not a new phenomenon in India. In the mid-1960s there was a period of industrial stagnation, when economists argued this was due to the drop in agricultural growth in 1965-67. During the mid-1960s the RBI (Reserve Bank of India) imposed two requirements on the banking sector: firstly, priority sector lending. This ensured that banks made a significant portion of their loans to farmers for agriculture and this also meant that small and medium farmers also were able to borrow at subsidized rates. The other was a statutory liquidity ratio, which determined the amount of government securities the banks had to hold as percentage of demand. This put a limit on the amount of money banks could create. This resulted in lower inflation, except in response to unfavourable oil shocks or poor weather conditions (Siddiqui, 2014).

Under dirigisme, industrial production was associated with the performance of the agriculture sector. It was said that a poor harvest meant lower incomes for farmers who then had little money left to spend on industrial goods. (Siddiqui, 1999) At the same time, government cuts in expenditure to control inflation adversely affected industrial demands. In short, both 
industrial demand and production were associated with the performance of the agricultural sector.

In fact, the poor performance of agriculture has deepened, especially since the liberal reforms and also the productivity of the agricultural sector in India continues to lag behind other major countries. There is a need to rethink state support not only for industrialisation, but also for agriculture. As Kaldor (1967) has emphasised, faster growth in the manufacturing sector is associated with the performance of the agricultural sector. Successful East Asian countries also point towards the crucial developmental role played by the state.

However, the current lower industrial growth or near stagnation seems to be different from the previous one. Industrial stagnation took place in both 2011-12 and 2013-14, when agricultural output was good, but the industrial growth rate did not increase. The good agricultural performance was expected to boost industrial output, but this did not happen. The post-liberalisation period has been marked by a new development, which is very different from the pre-liberalisation period, namely, the Indian economy is now much more closely integrated with the world economy (Patnaik, 2013a).

\section{The Performance of the Industrial Sector}

The manufacturing sector has been technologically a dynamic sector and absorbed large quantities of skilled labour migrating from the rural sector and also benefitted the economy by raising incomes and productivities. In the past manufacturing showed the way for rapid growth to the rest of the economy. However, recent globalization has led to deindustrialization within some developing countries. Due to this the share of the economy's labour employed by the manufacturing sectors is less that unity $(\sigma<1)$ (Rodrik, 2016).

The arguments for industrial policy put forward by Kaldor (1967) that faster manufacturing sector growth propels the rest of the economy following Verdoon's law of positive externalities. Industrialisation is crucial because it can absorb a huge labor force through employment creation, raise productivity, has spill-over effects on other sectors and can earn foreign exchange revenue. (Nicholas, 2005) India's manufacturing output has risen $6 \%$ per annum since 1991, and there has certainly been improvement in the variety and quality of consumer goods produced locally. But import intensity has risen as well. The manufacturing growth rate is higher than for the preceding quarter century, but the same as in the 1980s, when some market-friendly measures were applied to boost private investment. In the 1980s, India began gradually to liberalise trade and by mid-1980s India's current account deficit and external debt started to grow. And also imports grew at a faster rate and the rising current account deficit was increasingly financed by commercial borrowing and non-resident India (NIR) remittances, which meant greater dependence on foreign sources and higher costs and short-term financing. As a result, India's foreign debt sharply rose from US\$20.5 billion in 1980 to US\$ 72 billion in 1992, making India the world's third largest debtor after Brazil and Mexico (Nagaraj, 2017). India's share in global merchandise increased from $0.5 \%$ in 2000 to $1.5 \%$ by 2015 , while India's share in the global of services rose faster over the same period i.e. from $1 \%$ to $3 \%$ (CSO, 2015).

In the 1990s, India's important manufacturing sector such as capital goods, heavy electricals and cotton textiles have experienced significant unutilised capacity due to lack of domestic demand for their products. The reason seems to be the price ratio between manufactured goods and agricultural commodities declined between 1991 and 1999. It is well known that 
food enters in a significant way into the cost of living indices of agricultural workers and the rural poor, who constitute a significant proportion of the rural population. For instance, the agriculture cost of living index for agriculture was $114.14 \%$, while industrial worker index cost of living rose to $110.4 \%$ between 1991 and 1999 (Patnaik, 2013b). Moreover, government expenditure declined as a proportion to GDP i.e. $36.96 \%$ in 1991 to $33.4 \%$ in 1999. And also the ratio of development outlay to GDP declined from $22.1 \%$ to $18.5 \%$ for the same period, while the non-development outlay such as interest payments as a proportion of GDP rose from 5.2\% to 6.2\% between 1991 and 1999 (Siddiqui, 2015).

In early 2000s, the rise of demand for IT services abroad has created IT services boom. As profits in this sector rose and it provided opportunities for further foreign capital investment collaborations in this sector. This period also coincided when India began to be seen as a favoured destination for foreign financial investors. This was also the period when Indian businesses went for excessive borrowings from foreign sources. Moreover, in recent years the capital inflows exceeded the balance of payments needs and it led to the creation of conditions for an appreciation of Indian currency. In fact, excessive foreign capital inflows have led to building surplus foreign exchange reserves, but these reserves are not earned through exports but are borrowed from foreign capital investors. It seems that such economic policies are fragile as its success heavily relies on foreign capital inflows, if such inflows reverse back due to external reasons or global situation, then it could lead to a similar situation as happened during the 1997 East Asian crisis.

It seems that pro-market reforms have hardly had any long lasting impact on the manufacturing sector; its GDP share has stagnated at around $14 \%$ and that of the industrial sector at $26 \%$ during the post-reform period. India's stagnation in the manufacturing sector is unique, compared with other East Asian economies, including China. These economies not only managed to raise their manufacturing share in domestic output and global trade, but also increased the technological content of their exports. (Rodrik, 2011)

There is no doubt that Industrial production has diversified with improvements in the quality of the products. However, the manufacturing sector's share has stagnated at about $15 \%$, while the industrial share has stagnated at around $26 \%$ of GDP after the reforms. When we look at the longer trends, Indian industries have not done very well. For instance, when we compare with China, both countries had roughly same levels of industrialisation in the 1950s, India rather had slightly more developed industries than China, but by 2015, China became world's second largest manufacturing country, while India ranked $10^{\text {th }}$, producing one-quarter of China's industrial output (Nagaraj, 2017). Since reforms, the growth rate of the manufacture sector has averaged $7 \%$, which is higher than the preceding quarter century, but almost similar as in the 1980s. India's share in global merchandise trade has risen from $0.5 \%$ in 2000 to $1.5 \%$ in 2016 , and the share of services exports increased from $1 \%$ to $3 \%$ for the same period (Nagaraj, 2017).

In 2000s, the Indian government initiated policies to promote industrialisation through the creation of SEZs (Special Economic Zones) and land acquisition for infra-structure and industrial development. They were made open to private and foreign capital, which led to land becoming commercialised with the backing of local and foreign capital and ultimately private developers took this over for residential and commercial purposes rather than industrial land use (Bhaduri, 2008). India has taken a number of policy measures to encourage investors and has reduced import tariffs. In terms of openness it is comparable to other East Asian countries. Then the question arises as to why India's manufacturing output 
and exports have not risen and are still performing poorly, in comparison with its East Asian peers.

The proponents of liberal reform would say that those reforms have not gone far enough; as some restrictions still remain regarding foreign investment, and labor market regulation. However, there is no clear theoretical or empirical evidence to indicate a positive correlation between liberal market reforms, and output and export growth. (Rodrik, 2011) India's promarket policy has led to an increase in capital inflow, largely in private equity investment.

Following financial liberalisation, India has reduced the availability of credits to local businesses and large firms are allowed to borrow internationally. In contrast to India, China still provides cheap credit and trade credit to businesses wishing to enter the international market. Liberal reform has also led to the reduction in spending on domestic industrial R\&D, in the hope that private and foreign firms would fill the gap, but this has not happened, while China has increased spending in this area as well. For example, in 1996, R\&D represented the same share of GDP for both India and China, about $0.6 \%$, but by 2011 the ratio for China had tripled, whereas India's ratio has risen marginally to $0.8 \%$ (Siddiqui, 2014). It was also expected that the imposition of liberal (market-friendly) reforms would boost the laborintensive export sector and overall exports would rise. However, this did not happen (Bhaduri, 2008).

\section{The Performance of the Agricultural Sector}

The dirigiste economic strategy in the 1950s brought a very positive change in the industrial sector by building industries in key areas such as power generation, steel and manufacturing industries. However, it failed in achieving land reforms in the sense that curbing the rural power of the landlords and bringing socio-economic equality in the countryside. Despite of a number of land reform measures, it did not break the social and economic power of the landlords and also failed to fully implement 'land to the tiller' policy. The rural poor did not experience any betterment as the large number of these sections also belongs to the lower castes. During the mid-1960s, the government undertook measures to nationalise banks, which meant more credits were made available to agriculture sector and besides this subsidies were also extended to agriculture inputs to support 'Green Revolution'. These measures did achieve to increase food production and not to rely on food imports. But such dirigiste strategy promoted capitalist development in agriculture. However, it reached into inner contradictions, especially fiscal crisis of the state. And in the 1980s the government resorted to foreign borrowing, which provided a short term relief. However, the Gulf War and decline in remittances from Indian workers in that region and a dramatic rise in oil prices and finally collapse of Soviet Union has created a very challenging situation for India (Chandrasekhar, 2013).

Growth in the agricultural sector in terms of both GDP and output had decelerated in the post-reform period. For example, from 3.08\% during the 1980-1990, the agricultural growth declined to $2.57 \%$ during the period of 1992-2007 and in terms of output, the growth rate of food grains to $1.16 \%$ from $2.86 \%$ for the same period. It is alarming is that the food grains annual growth is far below the rate of population growth. The crisis in the agricultural sector is also related to the rise in the cost of production, decline in investments, capital formation, access to poor credits and poor selling prices (Siddiqui, 1999). The decontrol of fertilizers led to sharp increase in its prices. Table 2 analyses the share of agriculture in GDP and share of agriculture in employment from 1950-51 to 2014-15. The share of agriculture in GDP in 
1950-51 was $56.7 \%$, while its share in total employment was $85 \%$ for the same period. The share of agriculture in GDP fell sharply and by 2014-15 it was 13\%, while the fall in the share in the agricultural employment was much slower $(55 \%)$ and more than half of the population still depends on agriculture for their livelihood as shown in Table 2.

\begin{tabular}{|l|l|l|}
\hline Year & $\begin{array}{l}\text { Share of agriculture in GDP at } \\
1999-2000 \text { prices }(\%)\end{array}$ & $\begin{array}{l}\text { Share of agriculture in } \\
\text { employment }(\%)\end{array}$ \\
\hline $1950-51$ & 51.9 & 85.0 \\
\hline $1960-61$ & 47.6 & 77.3 \\
\hline $1970-71$ & 41.7 & 63.9 \\
\hline $1980-81$ & 35.7 & 60.0 \\
\hline $1990-91$ & 29.5 & 58.1 \\
\hline $2000-01$ & 22.3 & 57.3 \\
\hline $2005-06$ & 18.3 & 56.7 \\
\hline $2010-11$ & 14.6 & 56.0 \\
\hline $2013-14$ & 13.9 & 55.4 \\
\hline $2014-15$ & 13.4 & 55.0 \\
\hline
\end{tabular}

Table 2: Share of Agriculture in GDP and Employment in India.

Source: National Sample Survey various years, Central Statistical Organisation, Government of India, New Delhi.

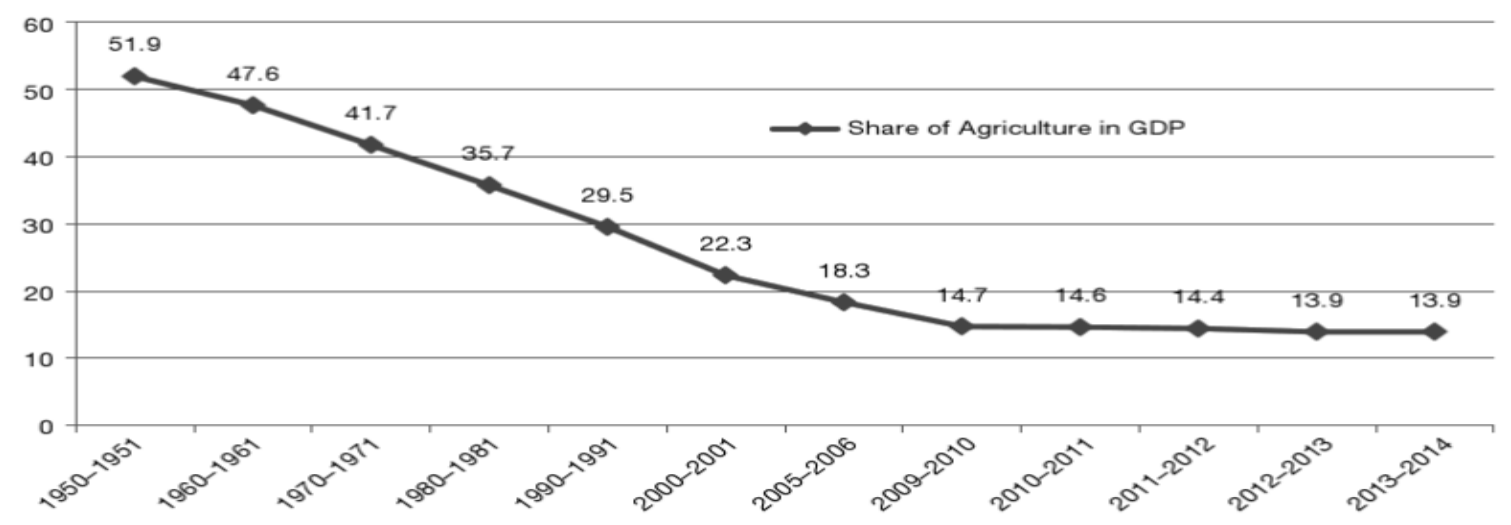

Figure 2: Share of agriculture in total GDP at constant prices of 2004-05 (in \%), 1950-2015. Source: Computed from the the Planning Commission data, Government of India, various years. (accessed on 12 December 2017)

However, a dramatic change in the performance of the agricultural sector was seen soon after the independence when it grew at the rate of 2.6\% annually between 1950 and 1965, far more than during the pre-independence period (Siddiqui, 2014). The main reason for this development can be attributed to land reforms, especially the removal of absentee landlordism and the increase in public investment. However, public investment began to decline in the early 1980s and private investment fell as well. For the last five or six years, agricultural investment as a percentage of total investment has remained unchanged i.e. it was 6.7\% in 2009-10 and 6.5\% in 2012-13 (Chandrasekhar and Ghosh, 2015).

Between 1993 and 2013, the share of the agriculture sector in GDP declined from 25\% to merely $14 \%$, while the share of total employment declined from two-thirds to less than onehalf. This means that GDP per capita in agriculture sector has been only one-tenth of GDP 
per capita in the non-agriculture sector for the past twenty-five years. The share of manufacturing in GDP reached its peak of $17.3 \%$ in 1980 and remained around $16 \%$ until 1995 and further declined to $12.9 \%$ in 2015 (Nayyar, 2017).

Family division and fragmentation of land holdings has also led to low investment and thus low employment creation. Small plots of land under cultivation are unable to achieve economies of scale. In the absence of employment in the organised sector, the surplus rural workers, who are mostly unskilled, often migrate to seek employment in the informal sector to cities such as Mumbai or Delhi or to other states in Punjab and Haryana to earn an additional income. Despite all the hardship and uncertainty faced by small farmers, they have not completely given up their only secure source of livelihood, namely their land. (Siddiqui, 2012) A meagre plot of land may not provide a livelihood throughout the year, but may act as a valuable fall-back option (Balakrishnan, 2010). Agriculture continues to be a lifeline for more than half of India's population and government action through appropriate public policies has been crucial to ensuring the healthy performance of this sector over the decades since independence.

The share of public investment in the agricultural sector has declined since 1991. The percentage of gross capital formation (GCF) in the agricultural and allied sectors of the total GCF of the Indian economy showing a long-term decline from $45 \%$ in $1980-81$, to $22 \%$ in 1990-91 and just 7\% in 2010-11 (CSO, 2015). Under WTO pressure, in the name of global competition, Indian agriculture was exposed to global competition, and earlier protection such as agricultural support prices, input subsidies and public extension services were gradually reduced. Moreover, stagnation and even decline in the international commodity prices meant that Indian farmers had to work within a highly uncertain global environment.

Due to globalisation and the increased integration of the Indian economy into global markets, global finance has become more important for local big businesses. Financial capital is opposed to debt-financed spending by the government. The government views deficit financing as increasing the liquidity overhang in the system and therefore being potentially inflationary. Inflation would erode the real value of financial assets. Another crucial point is that debt-financing by the state can legitimise and provide an important role for the state, but this development would undermine the role of the market, which is anathema to global finance. As Patnaik observes:

"Any state action that operates independently of finance capital, that seeks to work directly instead of working through the promotion of corporate-financial interests, undermines the social legitimacy of capitalism, and especially of these corporatefinancial interests, for it raises the question: if the state is required to fix the system, then why do we need to system at all, why not simply have state ownership as such?" (Patnaik, 2013b:19)

According to official estimates India's GDP share increased from 4.8\% of world GDP in 2001 to $7 \%$ by 2016. This led to euphoric claims that India was emerging as a global economic power. However, the Indian economy remains among the poorest in the world. For instance, its per capita income (on a PPP basis) was estimated at just $\$ 5214$ in 2013 . The infant mortality rate per 1,000 live births was 41.1 in 2013 . Nearly two million children die there every year with over one-quarter (28\%) of those deaths linked to unsafe drinking water and poor sanitation (Chandrasekhar and Ghosh, 2015). 
The proponents of neoliberal reforms argue that India has not only managed to escape from the low-growth trap, which persisted until mid-1980s, but has managed to achieve higher growth rates. The figures do support such claims. For example, from 1950 to 1964, India's GDP grew on average 4.8\% per annum; in 1965-74 this was $3.4 \%$, and in $1975-1984,4.2 \%$. This rose to $5.9 \%$ in 1985-1995 and 7.2\% between 1996 and 2014. The other success that India has seen is the building up of a large foreign exchange reserve, which has currently risen to US\$ 360 billion, equivalent to 11 months by current standards. Of course, this represents a remarkable development compared to 1991, when its foreign currency reserve had fallen to the value of its imports to just two weeks and it had to pledge its gold reserves to borrow money temporarily from the IMF to pay for its balance of payments (Nayyar, 2017).

It was assumed that as a result of neoliberal reforms, Indian manufacturing would be a leading sector and it would grow quickly due to increased competition and the availability of new technologies and global markets (Girdner and Siddiqui, 2008). This did not happen. (See Figure 3) In 2010, industry's contribution to GDP was $47 \%$ in China, $39 \%$ in South Korea, $47 \%$ in Indonesia, $44 \%$ in Malaysia, and $45 \%$ in Thailand while in India, industry contributed only $27 \%$. India also failed to diversify the commodities composition of its exports, and its traditional exports continue to dominate. In recent years, its exports have fallen in absolute terms (See Figure 4).

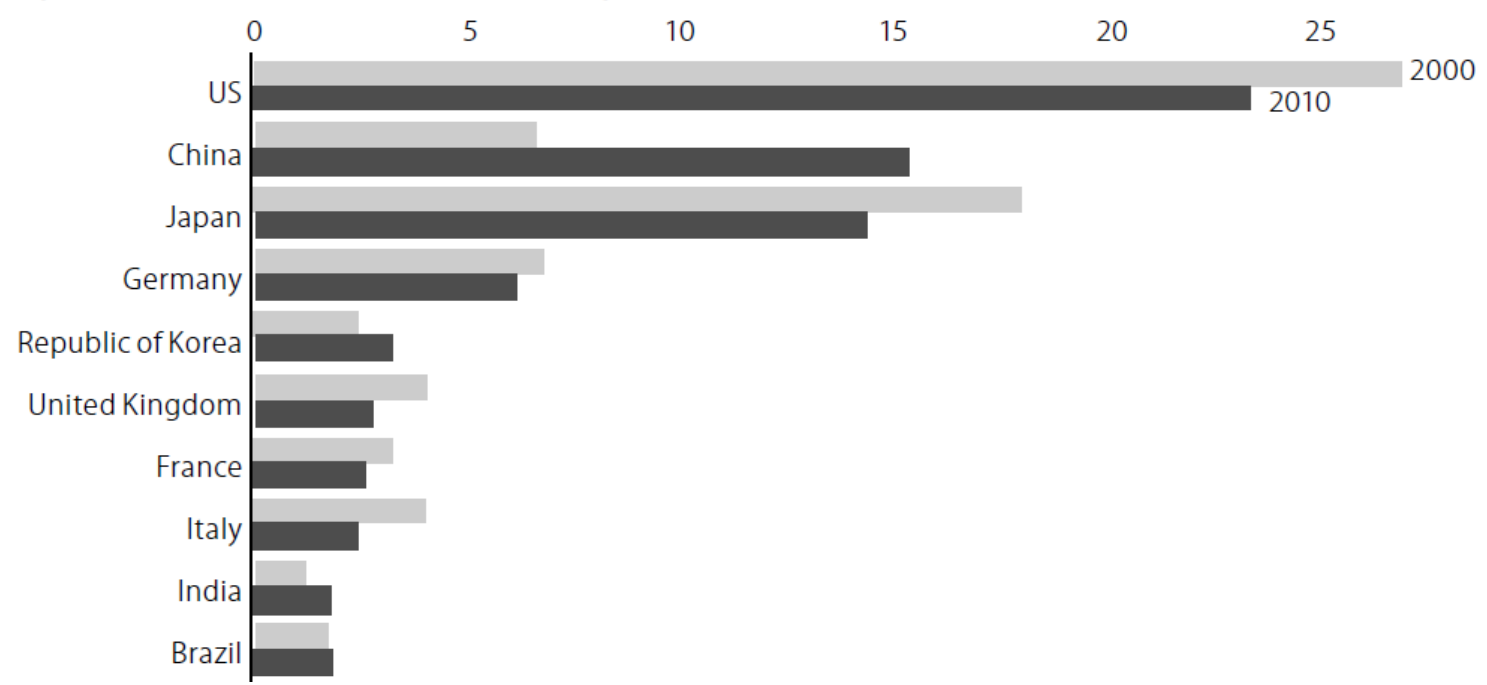

Figure 3: World's Top 10 Manufacturing Nations in 2000 and 2010.

Source: UNIDO's International Yearbook of Industrial Statistics, 2012.

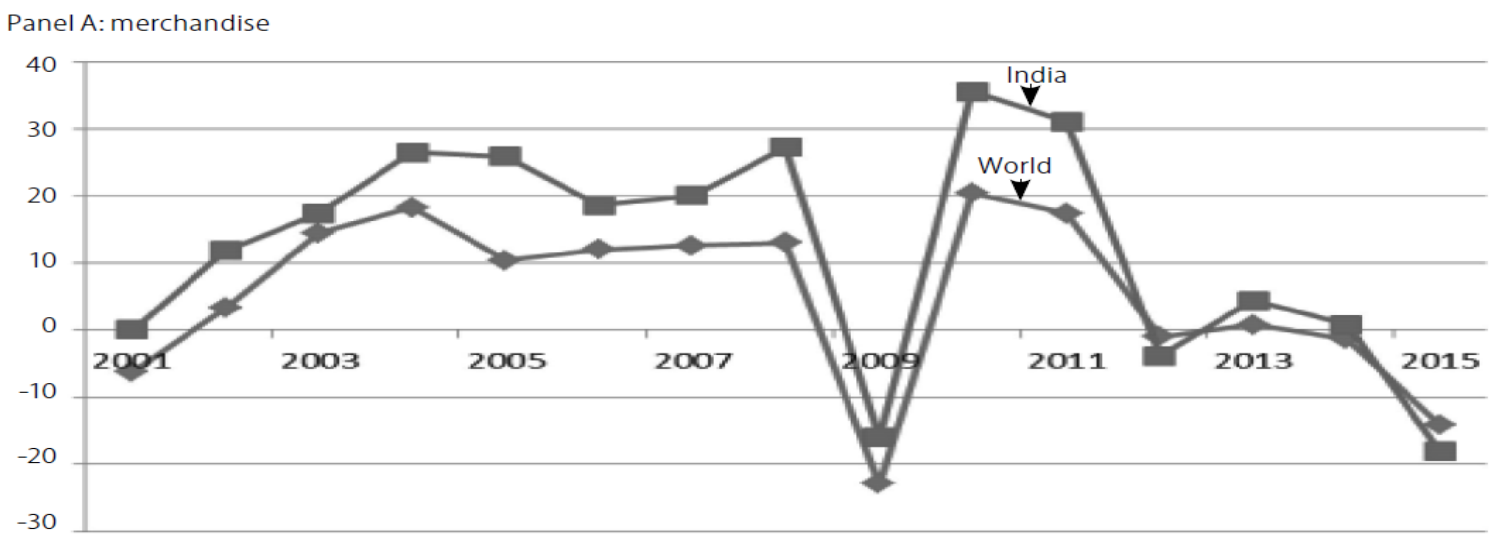


Figure 4: Annual Merchandise Export Growth Rate for India and the World from 2001 to 2015.

Source: R. Nagaraj, 2017, p63.

In India, the output in the organised manufacturing sector ${ }^{3}$ has increased since pro-market reforms were introduced while during the same period the total number of workers in the organised manufacturing sector rose by only $0.9 \%$ annually from 1981 to 2005 . The gross value added (GVA) in the manufacturing sector rose by $6 \%$ annually during the above period at 2004-05 prices. (Bhalotra, 1998) In other East Asian countries such as Japan, South Korea, Taiwan, Malaysia, Singapore (Siddiqui, 2016c) and more recently in China, the rapid expansion of manufacturing has absorbed the surplus labor force from the rural areas. However, in India, despite the high GDP growth rates, employment creation was negligible (NCEUS, 2009). Hence, this growth did not lead to employment generation. Bhalotra (1998) found that employment depends on expected cyclical changes in demand, productivity growth, and scale of production, hourly wages and hours of work. Her study, using state and industry-wise ASJ data sets, also found a significant negative correlation between the number of workers and hours of work between 1979 and 1988.

The National Commission for Enterprises in the Unorganised Sector (NCEUS) Report (2009) provides estimated figures for the employment of formal and informal workers in organised and unorganised sector in the entire economy of India, including the agricultural and nonagricultural sectors. The study emphasises the significant employment growth during the 1999 and 2005. Formal employment rose gradually from 33.6 million to 35 million, while employment in the organised sector increased rapidly from 54.9 million to 62.6 million. The report suggested that "the entire increase in the employment in the organised sector over this period has largely been informal in nature". (NCEUS, 2009: 14) A number of studies have found that despite the rapid growth in GDP, employment generation in the organised manufacturing sector was far less impressive. This was due to a number of reasons including: adoption of capital-intensive techniques, the extension of working hours per day and the increase in man-days and changes in production in favour of less labor-intensive industries (Chandrasekhar and Ghosh, 2015).

\section{Poverty and Inequality}

It is important to analyse the outcomes of GDP growth on poverty and inequality since the adoption of neoliberal reforms. Some economists suggest that India's growth performance has been spectacular and that it has also made impressive gains in reducing poverty, while inequality has risen at modest levels (Anand and Thampi, 2016). However, critics argue that the nature of development has been far from inclusive, that poverty has not decreased and that growth has accompanied by a huge increase in inequality (Balakrishnan, 2010). Poverty continues to be a major source of concern if we look at non-income dimensions of poverty such as access to schools, health care, energy and transport.

In India, the official procedure for setting the poverty line was based on consumption expenditure at which a specified calorie norm of nutritional intake is observed to be actually in some reference year which is taken as the base year. However, such estimates do not take into account the fact that the choice of base year is essentially an arbitrary one. The choice of

\footnotetext{
${ }^{3}$ Officially the organised sector is defined as those industries employing 10 or more workers using power and those employing 20 or more workers without using power.
} 
an early year as a base year yields a favourable trend with a relatively declining headcount ratio of poverty. If we change the base year then we tend to get rising poverty rates.

The per capita food grain absorption data is defined as net output minus net increase in stocks. The per capita food grain absorption by the end of the $19^{\text {th }}$ century was $200 \mathrm{~kg}$ annually. However, this declined sharply to less than $150 \mathrm{~kg}$ by the mid- $20^{\text {th }}$ century (Blyn, 1966). According to FAO estimates, this figure began to increase gradually after independence and it reduced to $180 \mathrm{~kg}$ in 1990, but begins to decline soon after and in 2008 it declined to only $156 \mathrm{~kg}$. At present the government estimate is based on overall per capita consumption expenditure level at which these calorie intakes are achieved. This is defined as the 'poverty line' and calculated for a particular base year. This new official method of estimation differs from the earlier one, which estimated how many people have access to less than the stipulated calories and defined them as living below the poverty line. The official arguments are that food grain consumption declines as levels of income rise and people tend to diversify consumption away from food grains and spend money on other goods due to changing tastes and health care.

As shown in Table 3 below, the National Sample Survey Organisation (NSSO) estimated the official state-wise percentage of rural population from the calorie norms for the period of 2004-05 and 2014-15. Data indicate that in most Indian states, the calorie intake declined between 2004-05 and 2014-15, the only exceptions being Kerala and West Bengal. In Delhi, a slight decrease was witnessed, while the fall was much higher in Madhya Pradesh and Maharashtra. Overall, at national level, calorie consumption declined from 79.8 to 77.2 for the same period (see Table 3). As Prabhat Patnaik argues, "It is clear from the Indian experience that the period of high growth has actually witnessed an increase in hunger in the country. And since poverty in India, as elsewhere, is defined with respect to a minimum nutritional intake, there has been an increase in absolute poverty in the country. Indeed, the proportion of persons both in rural and in urban India falling below a certain daily calorie consumption norm has actually increased during the period of high growth" (Patnaik, 2013a:10).

\begin{tabular}{|l|l|l|}
\hline State & $2004-05$ & $2014-15$ \\
\hline Andhra Pradesh & 83.3 & 72.5 \\
\hline Assam & 84.1 & 86.5 \\
\hline Bihar & 78.2 & 78.8 \\
\hline Chhattisgarh & 84.1 & 81.6 \\
\hline Delhi & 81.9 & 81.1 \\
\hline Gujarat & 84.3 & 88.5 \\
\hline Haryana & 67.3 & 68.6 \\
\hline Himachal Pradesh & 65.9 & 50.0 \\
\hline Jammu and Kashmir & 65.3 & 57.1 \\
\hline Jarkhand & 85.5 & 81.2 \\
\hline Karnataka & 89.8 & 82.6 \\
\hline Kerala & 79.6 & 81.8 \\
\hline Madhya Pradesh & 87.0 & 75.9 \\
\hline Maharastra & 86.5 & 77.8 \\
\hline Odisha & 77.6 & 77.8 \\
\hline Punjab & 67.1 & 62.7 \\
\hline
\end{tabular}




\begin{tabular}{|l|l|l|}
\hline Rajasthan & 73.6 & 65.7 \\
\hline Tamil Nadu & 88.2 & 87.5 \\
\hline Uttar Pradesh & 73.0 & 76.4 \\
\hline Uttarakhand & 74.3 & 51.6 \\
\hline West Bengal & 77.7 & 79.4 \\
\hline India & 79.8 & 77.2 \\
\hline
\end{tabular}

Table 3: Percentage of Indian Rural Population below the Calorie Norms, 2004-05 and 201415 , State-wise in India.

Source: Calculation/estimation based on NSSO data, New Delhi, Government of India.

In terms of the social indicators India's performance has been bad of 188 countries compiled by the UNDP, India is ranked 130. The UNDP statistics show that nearly $48 \%$ of India's children aged five or under are malnourished. Public expenditure on health is meagre i.e. $1.3 \%$ of the GDP in 2015. India cannot become modern nation if its lowest income groups have no access to health. Compared to India, the figure for China's public spending on health is $3 \%$, more than double that of India while the average figure for western European countries is $8 \%$ of GDP (Siddiqui, 2016a).

Nearly $40 \%$ of India's population fall into the lowest income group and a high proportion of these are Dalits (also known as untouchables), or belong to tribal or religious minorities, particularly Muslims (Siddiqui, 2017b; 2017c). Due to poverty, the poor schooling and health of their young people puts them at a disadvantage in the job market. Good quality education and health care are beyond their means and these negative factors affect their earning potential. In fact, all these factors have certainly given rise to the widespread social unrest witnessed during the last twenty-five years. Moreover, the skewed income distribution will lead to further deterioration in aggregate demand and growth potential will be adversely affected.

The inequality in distribution of wealth since 1991 in India is shown in Table 4. The Gini Coefficient of total assets was as high as 0.74 and 0.75 respectively in 2014. These coefficients increased by as much as 8 percentage points between 2002 and 2014. Data indicates that there has been massive increase in wealth inequality since 2002. Anand and Thampi (2016) conclude that, in both rural and urban areas, inequality has exacerbated for the last decades. In recent decades in India, the top 10\% holds at least $70 \%$ of the wealth in 2016. Forbes' list of US dollar billionaires confirms this. For example, India had only two individuals in that list in 1995, but this number rose to 46 in 2012 and 55 in 2014. In the most recent list, Forbes (2016) claims that Indian numbers have reached 100.

\begin{tabular}{|l|l|l|l|l|l|l|l|l|l|}
\hline & \multicolumn{3}{|l|}{ Rural } & \multicolumn{3}{l|}{ Urban } & \multicolumn{2}{l|}{ Total } \\
\hline & 1991 & 2002 & 2014 & 1991 & 2002 & 2014 & 1991 & 2002 & 2014 \\
\hline $\begin{array}{l}\text { Total } \\
\text { assets }\end{array}$ & 0.62 & 0.63 & 0.67 & 0.73 & 0.71 & 0.77 & 0.65 & 0.66 & 0.74 \\
\hline $\begin{array}{l}\text { Net } \\
\text { worth }\end{array}$ & 0.62 & 0.63 & 0.68 & 0.74 & 0.72 & 0.78 & 0.66 & 0.67 & 0.75 \\
\hline
\end{tabular}

Table 4: Gini Coefficient by Sector in India, 1991-2014

Source: Reproduced from Anand and Thampi, 2016:61; $48^{\text {th }}, 59^{\text {th }}$ and $70^{\text {th }}$ rounds of All India Debt and Investment Survey (AIDIS).

Although child malnutrition rates in India have declined rapidly during the past decade, they still rank amongst the world's highest. Nearly $48 \%$ of children under-fives in India had 
stunted or below average growth for their age in 2006. This had dropped to $39 \%$ in 2014, but that still represents over 47 million children. Malnourishment not only has physical effects but also leads to delays in the development of cognitive skills. If malnutrition rates continue to decline, India, which is currently lagging behind several poorer African countries, will achieve similar rates to those found in Ghana or Togo by 2030 (Lomborg, 2016).

The on-going dispossession of India's rural sector, for instance, via income deflation imposed on rural society makes even simple reproduction difficult to maintain. The on-going crisis in the agricultural sector, has led to the loss of over 200, 000 lives due to farmer suicides in the last two decades. It is clear evidence of income deflation which is the direct result of the adoption of neo-liberal economic policy, meaning that the state is no longer able to support farmers against encroachments of big capital, in order to retain the confidence of global financial capital.

\section{Concluding Remarks}

In 1991, India made a U-turn in matters of economic policy, especially regarding the role of the state in economic development. In the 1950s, the prevailing idea in government circles shifted from a belief that the state could do nothing wrong to a belief that it could do nothing right. The current prevailing ideology is that neoliberal policy is the only option and this prosperity will ultimately trickle down to the poor (Siddiqui, 2012). However, according to Yeldan (2006), the IMF-led SAP has created a new international division of labor, where industrialization and self-reliance has been abandoned. Whilst domestic markets are integrated with global markets under marginalised conditions and as a result the domestic economy has become more vulnerable to external shocks.

The policy objective of the governments' macroeconomic policy must be growth with higher levels of employment. The problem is accentuated by the mainstream orthodoxy, which advocates a restrictive fiscal policy and a tight monetary policy. Fiscal austerity means cuts in public expenditure, welfare and social spending, which undermines growth. The tight monetary policy has an adverse impact on growth as higher interest rates discourage private investors.

The study has argued that the twenty-five years under neoliberal reforms show some positive changes in India's economy such as GDP growth rates, FDI, and improvement in the balance of payments situation. It seems that the government is happy to proclaim that FDI has risen and the balance of payments has improved, and that more imported consumer goods are available on the market, but most of people have not seen any benefits. The agricultural sector has suffered its worst crisis during recent decades, reflected in the rise in farmers' suicides.

This study contributes with the highlighting the importance of agriculture sector and the importance of linkages between agriculture and industries, which has been neglected so far, by focusing of GDP growth under the neoliberal policy in India. Further this study has argued that the manufacturing sector has not picked up, despite the adoption of pro-market policies and the availability of cheap labor and natural resources for labor-intensive exports. The manufacturing sector's share in the GDP has stagnated, and its share of merchandise exports has declined, while imports have risen sharply. This is not to suggest that India should go back to the pre-liberal period of import substitution industrialisation. However, policy change is required to assist the manufacturing sector and exports through developmental state policy. 
This almost stagnation in industrial growth has meant dismal employment generation, while at the same time the expansion of the highly capital-intensive services sector, especially information technology, has led to very low rates of employment generation. The information technology industries have necessarily been confined to a narrow highly educated professional segment of the population.

The study found that India's progress towards industrialisation has been disappointing and the optimism that foreign capital and technology would bring efficiency and boost growth of manufacturing has been proved incorrect. In fact, manufacturing is very important for a country like India, where rapidly growing manufacturing besides earning foreign capital, can utilise labour, increase productivity and incomes through linkages and spill overs in the other sectors.

The neoliberal reforms overlooked the agriculture sector and this seems to be a deliberate policy as the government was keen to sort out balance of payments crisis and seems to have no long term strategy. This decision was difficult to understand, as in Indian economy, about two-thirds of the workforce was directly or indirectly employed in agriculture sector and also more than three-quarter of the poor live in the rural areas. The economic reforms did not take into consideration this very important sector.

This study concludes that despite higher growth, employment creation has been dismal, poverty persists and inequality has risen since the launch of economic liberalisation. The Indian economy now confronts a deepening crisis in the agriculture and in manufacturing sector, which could undermine any future growth prospects. Therefore, the sector needs massive investment especially in irrigation and soil conservation. The study has also argued that the growth in employment opportunities can help to provide a solution to India's problems, particularly to revive growth by enlarging domestic demands and reducing inequality.

An alternative economic policy should be based on raising incomes of agricultural workers, expanding domestic markets, reviving public investment in crucial areas such as irrigation, education and health. Such measures would eliminate illiteracy and improve health and will raise productivity. To ensure a level playing field it is important for the state to intervene to create efficient markets. India needs to redefine the role of the state for economic development and the country needs an interventionist policy. By this, I do not mean blanket state support as in the past, but a strategic policy to support industry and agriculture.

\section{References}

- Amsden, A. 2003. The Rise of "The Rest"- Challenges to the West from the Late Industrialising Economies, London: Oxford University Press.

- Anand, I. and A. Thampi. 2016. "Recent Trends in Wealth Inequality in India", Economic and Political Weekly, 50(50):59-67.

- Bagchi, A.K. 1976. "De-industrialization in India in the nineteenth century: Some theoretical implications", Journal of Development Studies, 12(2):135-164.

- Balakrishnan, P. 2010. Economic Growth in India, New Delhi: Oxford University Press.

- Bhaduri, A. (2008) "Predatory Growth", Economic and Political Weekly, 43(16):1014. 
- Bhagwati, J.1993. India in Transition: Freeing the Economy, Oxford: Clarendon Press

- Bhalotra, S.B. 1998. "The Puzzle of Jobless Growth in Indian Manufacturing", Oxford Bulletin of Economics and Statistics, 60(1):5-32.

- Blyn, G. 1966. Agricultural Trends in India 1891-1947: Output, Availability and Productivity, Philadelphia: University of Pennsylvania Press.

- Central Statistical Organisation (CSO). 2015. New Delhi, Government of India.

- Chandrasekhar, C. P. and J. Ghosh. 2015. Growth, Employment Patterns and Inequality in Asia: A Case Study of India, ILO Asia-Pacific Working Paper Series. http://www.ilo.org/public/libdoc/ilo/2014/486985.pdf

- Chandrasekhar, C.P. 2013. "Fragile Foundation: Foreign capital and Growth after Liberalisation", Social Scientist, 41(1/2):17-33, January-February.

- Forbes. 2016. "The World's Billionaires". (Accessed on 20 November, 2017). http://www.forbes.com/billionaires/

- Girdner, E.J. and K. Siddiqui. 2008. "Neoliberal Globalization, Poverty Creation and Environmental Degradation in Developing Countries", International Journal of Environment and Development, 5(1):1-27, January-June.

- Joshi, V. and I.M.D. Little. 1994. India: Macroeconomics and political economy 1964-1991, World Bank, Washington DC: Oxford University Press.

- Kaldor, N. 1967. Strategic Factors in Economic Development, New York, Ithaca

- Krueger, A. 1987. "Rent Seeking”. Eatwell, J, Milgate, M. and Newman, P. (edi) The New Palgrave: a dictionary of economics, vol. 4, pp.147-149, London: Macmillan.

- Lewis, W.A. 1954. Economic Development with Unlimited Supplies of Labor, Manchester School of Economic and Social Studies, 22(2):400-451.

- Lomborg, B. 2016. "Feeding infants well starts a virtuous circle", Hindustan Times, December 30, New Delhi. http://www.hindustantimes.com/opinion/india-s-survey-to-measure-child-nutritionlevels-is-an-excellent-step-forward/story-MNcpqANR7jzZkh0t942liL.html

- Maddison, A. (1995). Monitoring the World Economy, 1820-1992, Development Centre of the OECD, Paris: OECD.

- Nagaraj, R. 2017. "Economic Reforms and Manufacturing Sector Growth: Need for Reconfiguring the Industrialisation Model", Economic and Political Weekly, LII (2):61-68, January 14.

- Nayyar, D. 2017. "Economic Liberalisation in India: Then and Now", Economic and Political Weekly, LII (2):41-48, January 14.

- NCEUS (National Commission for Enterprises in the Unorganised Sector). 2009. The Challenge for Employment in India: An informal economic perspective, vol. 1, New Delhi.

- Nicholas, H. 2005. "Introduction: Putting Industrialization Back into Development", Development and Change, 36 (6):1031-1033.

- Nurkse, R. 1953. Problems of Capital Formation in Underdeveloped Countries, Oxford: Basil Blackwell.

- Patnaik, P. 2015. "The Nehru - Mahalanobis Strategy”, Social Scientist, 43(3/4):3-10, March-April.

- Patnaik, P. 2014. "Imperialism and Agrarian Question", Agrarian South: Journal of Political Economy 3(1):1-15.

- Patnaik, P. 2013a. "Independent India at Sixty-Five", Social Scientist, 41 (1/2):5-15, January-February. 
- Patnaik, P. 2013b. "Finance and Growth under Capitalism", pp. 12-22, B. Dasgupta (ed.) Non-mainstream Dimensions of Global Political Economy, Oxford: Routledge.

- Rodrik, D. 2016. "Premature Deindustrialization", Journal of Economic Growth, 21:1-33. DOI: 10.1007/s10887-015-9122-3.

- Rodrik, D. 2011. The Globalisation Paradox: Democracy and the Future of the World Economy, New York: WW Norton \& Company.

- Rodrik, D. 2002. “After Neoliberalism, What?” Harvard University. http://cemi.ehess.fr/docannexe/file/2787/rodrik2002.pdf

- Routray, S. 2015. "The Post-development Impasse and the State in India", Third World Quarterly 36 (10):1906-1921.

- Siddiqui, K. (2017a) "Capital Liberalization and Economic Instability", Journal of Economics and Political Economy 4(1):659-677, March.

- Siddiqui, K. (2017b) "Globalization, Trade Liberalisation and the Issues of Economic Diversification in the Developing Countries", Journal of Business \& Economic Policy 4(4):1-16.

- Siddiqui, K. (2017c) Hindutva, Neoliberalism and the Reinventing of India, Journal of Economic and Social Thought 4(2):142-186, June. ISSN 149-0422.

- Siddiqui, K. 2016a. "Will the Growth of the BRICs Cause a Shift in the Global Balance of Economic Power in the 21st Century?" International Journal of Political Economy 45(4):315-338, Taylor \& Francis.

- Siddiqui, K. 2016b. "International Trade, WTO and Economic Development", World Review of Political Economy 7(4):424-450, winter, Pluto Journals.

- Siddiqui, K. 2016c. "A Study of Singapore as a Developmental State", Young-Chan Kim. (edi) Chinese Global Production Networks in ASEAN, pp.157-188, London: Springer.

- Siddiqui, K. 2015. "Challenges for Industrialisation in India: State versus Market Policies", Research in World Economy 6(2):85-98. ISSN 1923-3981.

DOI.org/10.5430/rwe.v6n2p85

- Siddiqui, K. 2014. "Contradictions in Development: Growth and Crisis in Indian Economy”, Economic and Regional Studies 7(3):82-98. ISSN 2083-3725.

- Siddiqui, K. 2012. "Developing Countries Experience with Neoliberalism and Globalisation", Research in Applied Economics 4(4):12-37, December.

DOI: $10.5296 /$ rae.v4i4.2878

- Siddiqui, K. 2009. "The Political Economy of Growth in China and India”, Journal of Asian Public Policy 1(2):17-35, March, Routledge. ISSN 1751-6234.

DOI: $10.1080 / 17516230902734528$

- Siddiqui, K. 1999. "New Technology and Process of Differentiation: Two Sugarcane Cultivating Villages in UP, India", Economic and Political Weekly 34(52):A39-A53, December 25. ISSN (Online) - 2349-8846

- Siddiqui, K. 1998. "The Export of Agricultural Commodities, Poverty and Ecological Crisis: A Case Study of Central American Countries", Economic and Political Weekly, 33 (39):A128-A137, September 26. ISSN (Online) - 2349-8846. 
- Stiglitz, J. 2010. Free Fall: America Free Markets and the Sinking of the World Economy, New York: W.W. Norton.

- Srinivasan, T.N. 1993. "Demand Deficiency and Indian Industrial Development" P. Bardhan et al. (edi.). Development and Change: Essay in Honour of KN Raj, Delhi: Oxford University Press.

- UNIDO. 2012. International Yearbook of Industrial Statistics, (Accessed on 22 November). https://www.unido.org/resources/.../flagship.../international-yearbookindustrial-statisti...

- Williamson, J. 1990. The Progress of Policy Reforms in Latin America, Washington DC: Institute for International Economics.

- World Bank, 2016 Dancing with the Giants: China, India, and the Global Economy, World Bank, https://openknowledge.worldbank.org/handle/10986/6632

- Yeldan, Y. 2006. "Neoliberal Global Remedies: From Speculative-Led Growth to IMF-Led Crisis in Turkey", Review of Radical Political Economics, 38(2):193-213, spring. 